\title{
Key Trends in the Transformation of Religious Consciousness in the Digital Society
}

\author{
Pelageya Nikolaevna Panaitova \\ Kazan Federal University, RUSSIA \\ (iD) 0000-0002-0390-4510 \\ pelageya.panaitova@mail.ru
}

\section{Artem Pavlovich Solovev}

Kazan Federal University, RUSSIA

(D) 0000-0003-4376-9752

$\square$ artstudium@yandex.ru

\begin{abstract}
ARTICLE INFO
Received: 27 June 2019

Accepted: 16 October 2019

Published: 10 November 2019

DOI: https://doi.org/10.29333/ojcmt/6277

ABSTRACT

The paper is devoted to the issue of identifying the main trends in the transformation of religious consciousness under the influence of digital modernization of modern society. The methodological basis of the study is constructionalism which allows us to understand religious consciousness as a construct that is transformed under the influence of digital technologies. The paper also relies on the theory of "compensation of the negative consequences of modernization" by G. Lubbe, in which religion is a way of compensating for the erosion of identity in the global world, as well as the loss of stable semantic guidelines in a world of accelerated obsolescence of experience. The paper determines that religious consciousness is polarized during the identified transformations which include "direct", "instrumental" and "functional" changes. This polarization is expressed in the fact that the growth of liberalization, rationalization and pluralization of religious consciousness and the simultaneous reaction to these processes in society lead to an increase in the value of conservation, fundamentalist ideas in the religious consciousness of a digital society. Based on this, it is concluded that the growth of religious fundamentalism is directly related to the intensity of the negative consequence growth of digitalization, globalization, acceleration and rationalization of the life of society as a whole, as well as in the same direct connection with the intensity of modernization of religion itself.
\end{abstract}

Keywords: modernity, religious consciousness, digital society, compensation theory of modernization, religious liberalism, religious fundamentalism

\section{INTRODUCTION}

Modern society is digital, which is a new form of modern civilization society based on the anthropocentric attitudes and ideals of the Enlightenment project (individual freedom which implies a person's power over himself and also over space, time, natural forces, life and death). To achieve its goals, modern civilization focuses on innovation, acceleration, rationality. In this sense, modern digital society is not very different from the society of early modern and industrial modern in terms of goals and values. 
The transition to new means of communication and information dissemination, the emergence of a new way of producing services and goods can be compared with the changes which brought us typography, compass and mills, and then steam locomotives, factories, and conveyors. Each of these technical innovations occurred under the influence of changes in society, but at the same time transformed this society itself. We will proceed from the fact that digital technologies also bring changes to social relations, and therefore to the life and the world of a person, to his consciousness. This also applies to religious consciousness. Thus, our goal is to identify areas of transformation of religious consciousness in a digital society.

\section{METHODS}

The theoretical and methodological basis of the study can be called the concept of Schutz (1962), according to which a person lives in a world of multiple social experiences associated with certain attitudes of consciousness. In this sense, the main aspect of the study will be the consideration of the transformation of the living world and the mindset of a believer, a religious person in a modernizing digital society. Therefore, it is assumed here that the everyday world of a believer is determined by the basic religious consciousness principles which are revealed by the phenomenology of religion Eliade (1959). Following it, religious consciousness will be understood as such a kind of social consciousness, the carriers of which are groups of believers. The peculiarity of religious consciousness is the belief in a transcendental, sacred matter ("Das Heilige" by Otto, 2014), or in that which is perceived as such. One can distinguish in the structure of religious consciousness the following:

1) Self-consciousness which correlates the "I" of the believing subject with certain ideas, images, and symbols,

2) The ability to distinguish between a sacred and a profane, and within the framework of understanding the sacred, there is the distinction between sacred and profane ideas, forces, objects, personalities, space, time,

3) Language (symbols) as a way of expressing attitudes (ideas, knowledge) (based on the fact that the boundaries of the living world are limited by the capabilities of a language of "speaking" of one's own faith).

Moreover, all these aspects are considered in the context of constructionalism which is the concept of constructing social reality from the point of view of which religion, religious consciousness, religious identity (as a way to realize religious self-consciousness), like all social structures and processes as a whole, are social constructs. In this aspect, we rely on the development of Schutz's ideas in the works of Bereger and Luckmann (1966). We also focus on the interpretation of constructionalism proposed by Burr (2003). In her opinion, among the basic principles of constructionalism, it is necessary to point out the need to understand the relationship between knowledge and social act (Burr, 2003, p. 3-5). With regard to religion, we are talking about religious knowledge, which in our case is connected with the life of a digital society. Constructionalism assumes that knowledge is always based on any social process and cannot exist outside this process. A critic of constructionalism, Hacking (1999), is close to this understanding of it.

Constructionalism assumes that knowledge is generated by social institutions that implement social projects in order to legitimize that knowledge as normative, "natural". Moreover, any change in the living world of a believer in this context involves a change in the characteristics of religious consciousness which occurs within the structure of the social reality constructing process. That is, in this case, we proceed from the fact that a 
change in society leads to a change in the living world of people, the worlds of everyday life, and, consequently, the living world of believers, which changes the meaningful side of religious consciousness settings.

The very context of the social transformation is supposed to be considered through the prism of the modernization theory and through the identification of the basic phenomena development features that relate to the social world of a modern man. At the same time, modernity will be considered here not so much through the prism of the modernity ambivalence theory by Bauman (1991), but through the compensation theory by J. Ritter, developed in the works of his student Lyubbe (1994), who continues to develop the social phenomenology program, proposed by Schutz. Within the framework of the compensation theory, modernization appears to be ambivalent, suggesting the occurrence of both positive and negative consequences for modern civilization itself. At the same time, modernity here is considered as having the ability to develop and use various mechanisms to level the negative effects of modernization, to "compensate" them. Thus, it is precisely the growing interest in religion in modern society that compensates for the distrust of constantly transforming (and therefore unstable) scientific knowledge, and the meaningless routinization of rationally arranged production of goods and services, and the acceleration of obsolescence of previous experience, and the erosion of identity in the context of globalization. Religion in this respect offers a meaningful, stable, rationally mastered irrational concept based on the historical experience of the past. Calling on settings of religious consciousness, a man gets what modern digital society cannot afford him. This increases the importance of religion in society, which in turn affects its characteristics.

Thus, within the framework of this methodology, it is proposed to consider the features that the development of digital technologies brings to the process of modernizing the living world of a modern person as a context of changes in the attitudes of religious consciousness that determine the characteristics of the living world of a believer. At the same time, recognizing the general characteristics of the modernity civilization society, we clarify that modern digital society is aimed at "digital" forms used for the implementation of the basic modern civilization principles. So, liberalization is expressed in the pluralization of virtual realities and the capabilities of networks for communication, globalization is expressed in the development and acceleration of anonymized network contacts, and rationalization represents itself in the calculation of possible solutions in a situation of choice, etc. All these processes influence on that the attitudes of religious consciousness are either being transformed according to general tendencies or are being transformed because they resist modernization.

\section{RESULTS AND DISCUSSION}

The social changes occurring due to the proliferation of information technologies include many processes that have arisen from about the beginning of the 1990s to the present day. Firstly, and this is the most important: there is an ever-increasing acceleration of obsolescence of previous experience and knowledge to a period shorter than the life of one generation, which implies both time saving and a decrease in trust in constantly ageing and updated scientific knowledge, and in news from official sources. Secondly, it is globalization aimed at reducing space, but at the same time eroding identity. Thirdly, this is the automation and rationalization of public life, including the robotization of technology, the development of Bigdata technology, and the virtualization 
of life while reducing real contact between people, the formalization of relations and the supplantation of the irrational matter from public life.

All these transformations have their consequences, which turn out to be significant for a change in religious consciousness. So, there is an increase in leisure time, with a simultaneous increase in the complexity of its meaningful spending. The opening of mass access to information leads to problems with a critical attitude to this information, which leads to chaotic knowledge, fragmentation of perception, and clip thinking. The virtualization of reality and accelerating the processes of information exchange lead to the relativization of reality, and its pluralization. The development of the possibilities of total observation in modern society leads to a change in the boundaries of personal and public, blurring of personal boundaries, including secret and explicit boundaries in politics.

These changes, one way or another, are forms of manifestation of such modern characteristics as liberalization, individualization and rationalization. It is they which determine the specifics of changes in religious consciousness in a digital society.

The transition from the traditional to the modernity society has produced a radical revolution in religious consciousness, which has felt and continues to feel the threat from modernization processes. So the liberalism and pluralism, individualism and rationalism which are common and inherent for the whole modernism civilization enter into religious consciousness as its characteristics, transforming the mindset of groups of believers. From a layman's point of view, the social changes that followed book printing, steam locomotive, atomic bomb, and the Internet did not change much in religious consciousness. But in fact, they intensified the liberalization, individualization, and rationalization of modern religious consciousness, but at the same time, they intensified critics of modernity from the point of view of religious principles. Religious consciousness reacted to ambivalent modernity also quite ambivalently with rationalizing and continuing to satisfy a person's interest in the irrational. It liberalized while reinforcing fundamentalism tendencies among believers.

Liberalization, individualization, and rationalization of religious consciousness allow it to survive, while religion itself, from the very beginning, seems to have been forced to be displaced from the modernity civilization as an obstacle to modernization. But the acceleration of social changes during a lifetime of one generation and the acceleration of past experience obsolescence due to digital technologies leads to the fact that a person feels increasing instability, the variability of the world, loses stability because it cannot build a holistic picture of the world. And searching for this integrity and constancy, man turns to religion.

Modern society cannot be called secular. Modern religion scholars speak of a postsecular world. The theory of secularization turned out to be untenable, which was also acknowledged by its developer, Berger $(1990,1999)$, and Taylor (2007) believes that in the modern world there is an ambivalent process of growth of religiosity in the individual consciousness with the displacement of religion from the public sphere. And in this sense, secularization should not be understood as the destruction of religion, but rather as a reduction in the presence of religion in public relations. However, this situation also seems to be controversial, since the principles of religious consciousness, which are based on something constant, stable, are in demand by modern society.

In the religious consciousness, in the life of a believer, there is always something that does not change and allows religious settings to be necessary for the digital society, but 
something changes so that the religious consciousness does not conflict with the trends of the new digital society, that is, for the self-preservation of religious settings at groups of believers. In general, a whole list of directions for changing religious consciousness in the context of digital modernization of society can be compiled. We suggest defining them as follows:

a) "Direct transformation of religious consciousness" - changes that involve the direct reception by the religious consciousness of the characteristics of modern consciousness and have occurred due to the need to comply with new digital realities (for example: religion goes into the virtual sphere, like many services, which corresponds to the liberalization trend of modern society);

b) "Instrumental transformation of religious consciousness" - changes that have occurred due to the need for self-preservation of religious consciousness in changing conditions (for example, the emergence of official websites of religious organizations to express an official conservative position, but using modern technologies);

c) "Functional transformation of the elements of religious consciousness" - a change that has occurred due to the need to perform new social functions (for example: to compensate for the negative effects of globalization, i.e., erosion of identity, for which religious consciousness transforms the concept of religious identity, which can also be formed in virtual space).

By analogy, it is possible to make a classification of what does not change in the religious consciousness, but is just preserved:

a) "Direct conservation of religious consciousness", which causes the inertia of religious consciousness;

b) "Instrumental conservation of religious consciousness" occurring due to the need for self-preservation of religious consciousness in changing conditions;

c) "Functional conservation of the religious consciousness elements", which occurs due to the need to perform new social functions (for example: the need to compensate for the negative consequences of accelerating and randomizing information on the Internet, while religious consciousness retains stable meanings that do not change and thereby allow screening, selecting and organizing information in a meaningful manner).

The ability to draw up such a list of directions for the transformation of religious consciousness in a digital society, which can be supplemented by complementary options for the conservation of its elements, indicates the ambivalence of the religious consciousness modernization, which is characteristic of modernity as a whole. At the same time, this modernization will produce negative consequences for religion itself, for the compensation of which the religious consciousness will produce new changes. In the future, this means that the growth of the society digitalization will lead not to curtailing religion, but to strengthening its significance as a way of compensating for the negative consequences of this modernization. Complementarily to this, the growth of digitalization, liberalization and rationalization of religion will lead to an increase in religious fundamentalism, which in turn will compensate for the negative consequences of religious modernization for religious consciousness. The growth of religious fundamentalism is directly related to the more intensive growth of the negative consequences of digitalization, globalization, acceleration and rationalization of the public life as a whole, as well as in the same direct connection with the intensity of modernization of religion itself. 


\section{SUMMARY}

The main conclusion from the above is that: changes in society under the influence of digital technologies lead to that the identity formation features are transformed in the religious consciousness, and the way to distinguish between the sacred and the profane becomes different. This is not to mention the fact that the language through which religious consciousness expresses its attitudes is changing, acquiring "digital" features. But the main thing is that religious consciousness is polarized in the course of the transformations identified in the paper, which include "direct", "instrumental" and "functional" changes. This polarization is expressed in that the growth of liberalization, rationalization and pluralization of religious consciousness and the simultaneous reaction to these processes in society lead to an increase in the value of conservation, fundamentalist ideas in the religious consciousness of a digital society.

\section{CONCLUSIONS}

So, the growth of religious fundamentalism is directly related to the intensity of growth of the negative consequences of digitalization, globalization, acceleration and rationalization of the life of society as a whole, as well as in the same direct connection with the intensity of modernization of religion itself. And this direct relationship belies the hopes expressed by supporters of secularism on the complete displacement of religion from public life, and by ultraconservative religious fundamentalists to complete coagulation of modernity civilization. Thanks to the Internet, religion is becoming more and more a part of social life and this is changing both society and religion. At the same time, modernity has always devised and continues to devise ways to compensate for the negative consequences of modernization. And religion, as related to human interest in the irrational, has always played an important role in this. In this sense, the need for a detailed analysis of religious consciousness is long overdue. This is also shown by the studies of many modern scholars on religious practices on the Internet. The time has come to move from identifying and researching new religious practices to what is happening in the religious consciousness under the influence of digitalization. And this is what is associated with further prospects for the study of this topic.

\section{ACKNOWLEDGEMENTS}

The work is performed according to the Russian Government Program of Competitive Growth of Kazan Federal University.

\section{REFERENCES}

Bauman, Z. (1991). Modernity and Ambivalence. Ithaca, N.Y.: Cornell University Press.

Berger, P. L. (1990). The Sacred Canopy: Elements of a Sociological Theory of Religion. Garden City, NY: Anchor Books.

Berger, P. L. (Ed.) (1999). The Desecularization of the World: Resurgent Religious and World Politics. Washington, D.C., Ethics and Public Policy Center.

Berger, P. L., \& Luckmann, T. (1966). The Social Construction of Reality: A treatise in the sociology of knowledge. Garden City, NY: Anchor Books.

Burr, V. (2003). Social Constructionism. New York: Routledge. https://doi.org/10.4324/ 9780203694992

Eliade, M. (1959). The Sacred and The Profane: The Nature of Religion. New York: Harcourt, Brace and Company. 
Hacking, I. (1999). The Social Construction of What? Cambridge, MA: Harvard University Press.

Lübbe, H. (1994). Im Zug der Zeit: Verkürzter Aufenthalt in der Gegenwart. Berlin:

Springer-Verlag Berlin Heidelberg. https://doi.org/10.1007/978-3-662-07852-5

Otto, R. (2014). Das Heilige. Über das Irrationale in der Idee des Göttlichen und sein Verhältnis zum Rationalen. München: Neuausgabe.

Schutz, A. (1962). Collected Papers, Vol. 1. Martinus Nijhoff, The Hague.

Taylor, Ch. (2007). A Secular Age. Cambridge, MA: Harvard University Press.

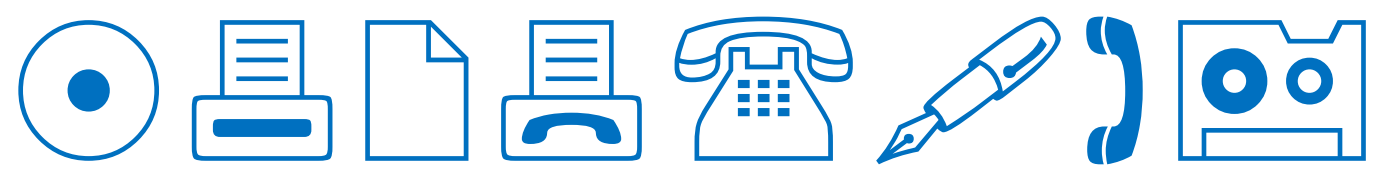

